\title{
Brexit, the Revocation of Article 50, and the Path Not Taken: \\ Wightman and Others for Judicial Review against the Secretary of State for Exiting the European Union
}

\section{A. INTRODUCTION}

The Supreme Court in Miller ${ }^{1}$ held that the UK Government could not trigger Article 50 Treaty on European Union to initiate the UK’s withdrawal from the European Union without Parliament's consent. Consequently, Parliament enacted the European Union (Notification of Withdrawal) Act 2017 to grant the Prime Minister (PM) the power to trigger Article 50. Theresa May accordingly gave notification of the UK's intention to withdraw on 29 March 2017. The UK is due to leave the EU on 29 March 2019.

Unresolved in Miller was whether an Article 50 notification can be revoked. The Supreme Court largely ignored the issue because it was common ground between the parties that notifications are irrevocable. ${ }^{2}$ A group of Scottish politicians has since raised this issue in the Scottish courts in Wightman. ${ }^{3}$ The petitioners sought judicial review of the UK Government's position on the revocability of Article 50, seeking a referral to the Court of Justice of the European Union (CJEU) on the matter as a question of EU law. In the Outer House of the Court of Session, Lord Boyd of Duncansby dismissed the petition. Referral to the CJEU was accordingly not sought, leaving the question of revocability unanswered.

This question is of profound relevance to the on-going Brexit discussions in Parliament and elsewhere. No matter its outcome, a referral to the CJEU could fundamentally alter the terms of the current debate. Confirmation of revocability allows the possibility of the UK changing its mind and remaining in the EU; confirmation of irrevocability removes any such possibility rendering calls for a second referendum on EU membership redundant.

The fatal deficiencies in the petitioner's claim may appear to make both appeal of the decision and future litigation on the issue by other parties unlikely. However, it is submitted that Wightman could mark the beginning rather than the end of finding a resolution on this

\footnotetext{
${ }^{1} R$ (Miller) $v$ Secretary of State for Exiting the European Union [2017] UKSC 5, [2018] AC 61.

${ }^{2}$ Ibid at para 26.

${ }^{3}$ Wightman $v$ Secretary of State for Exiting the European Union [2018] CSOH 8, 2018 GWD 5-72.
} 
This is the accepted manuscript submitted to Edinburgh University Press which will appear in volume 22, issue 3 (September 2018), pp. 417-422 of the Edinburgh Law Review (https://www.euppublishing.com/loi/ELR).

issue. This analysis will suggest that framing the petitioner's argument differently could address many of Lord Boyd's concerns, perhaps resulting in a different outcome. This provides opportunity for further litigation on revocability, which may successfully yield an answer to this outstanding yet constitutionally significant legal question at a crucial stage in the Brexit process.

\section{B. WIGHTMAN}

Section 27B of the Court of Session Act 1988 requires that permission to bring a judicial review action must be granted by the court. Permission is granted only if a petitioner can show "sufficient interest” and “a real prospect of success”. The petitioners in Wightman initially sought permission for judicial review from Lord Doherty in the Outer House. He refused permission, finding that the section 27B test was not met. He held that the action would constitute a breach of parliamentary privilege and would be based on a hypothetical question (given neither the UK Government nor Parliament had indicated an intention to revoke). ${ }^{4}$

The petitioners successfully appealed to the Inner House. Lord Carloway, who delivered the opinion of the court, noted that the petition failed to present a clear, succinct argument (as is required by Somerville). ${ }^{5}$ However, because of the important constitutional considerations raised therein, Lord Carloway considered that there might be an argument which would have "a real prospect of success" and that the CJEU would likely respond to any referral. The court therefore granted permission, with time for adjustment of the petition to address the requirements of Somerville. ${ }^{6}$

The adjusted petition sought a preliminary reference from the CJEU on whether the UK could unilaterally revoke its Article 50 notification. The petitioners additionally sought, on return of that reference, a declarator specifying "whether, when and how" a revocation could be effected. ${ }^{7}$

\footnotetext{
${ }^{4}$ Wightman $\mathrm{OH}$ (no 1) at paras 9-10, 14.

${ }^{5}$ Wightman $v$ Secretary of State for Exiting the European Union [2018] CSIH 18, 2018 SLT 356 at paras 10-11; Somerville v The Scottish Ministers [2007] UKHL 44, [2007] 1 WLR 2734 at para 65.

${ }^{6}$ Wightman $\mathrm{IH}$ at paras 30-34.

${ }^{7}$ Wightman $v$ Secretary of State for Exiting the European Union [2018] CSOH 61, 2018 GWD 19-236 at para 8.
} 
This is the accepted manuscript submitted to Edinburgh University Press which will appear in volume 22, issue 3 (September 2018), pp. 417-422 of the Edinburgh Law Review (https://www. euppublishing.com/loi/ELR).

Lord Boyd first considered the preliminary issue of the case's appropriateness for judicial review. He doubted, citing West, ${ }^{8}$ whether the court's supervisory jurisdiction was engaged given there was no alleged misuse of power; this was not, however, within judicial contemplation because it was not a matter of contention between the parties. ${ }^{9}$

Lord Boyd thereafter considered three substantive points: whether the question before the court was hypothetical; whether there was a breach of parliamentary privilege; and whether the CJEU would likely accept a reference from the court. He found against the petitioners on all three points.

First, Lord Boyd found that the question of whether the notification was revocable was merely hypothetical so not within the court's concern, per MacNaughton. ${ }^{10}$ The UK Government had made it clear that it would not seek to revoke the Article 50 notification, therefore the issue would not become "live” unless and until either the Government's policy or House of Commons majority changed. ${ }^{11}$

Regarding parliamentary privilege, applying Adams, Jackson and Axa, ${ }^{12}$ Lord Boyd found that the court was being asked to settle a legal dispute arising out of parliamentary discussions during the legislative process, which was a "clear and dangerous encroachment on the sovereignty of parliament". ${ }^{13}$ He reflected that "the rule of law should not be transposed to rule by the courts ... The court is not there to be used by one side or another to advance one side of a political debate." ${ }^{14}$ With respect to the parliamentary statements submitted as evidence, he distinguished Pepper $v$ Hart $^{15}$ and other judicial decisions ${ }^{16}$ from the present case on the basis of parliamentary privilege. ${ }^{17}$

\footnotetext{
${ }^{8}$ West $v$ Secretary of State for Scotland 1992 SC 385, 1992 SC 385.

${ }^{9}$ Wightman $\mathrm{OH}$ (no 2) at para 37.

${ }^{10}$ MacNaughton v MacNaughton's Trustees 1953 SC 387.

${ }^{11}$ Wightman CSOH (no 2) at paras 45-51.

12 Adams v Guardian Newspapers 2003 SC 425; R (Jackson and others) v Attorney General [2005] UKHL 56, [2006] 1 AC 262; Axa General Insurance and others v HM Advocate and others [2011] UKSC 46, [2012] 1 AC 868.

13 Wightman $\mathrm{OH}$ (no 2) at para 58.

14 Ibid at para 59.

151993 AC 593.

${ }^{16}$ Prebble v Television New Zealand Ltd [1995] 1 AC 321; Toussaint v Attorney General of Saint Vincent and the Grenadines [2007] 1 WLR 2825.

${ }^{17}$ Wightman $\mathrm{OH}$ (no 2) esp. paras 52-53, 61-62.
} 
This is the accepted manuscript submitted to Edinburgh University Press which will appear in volume 22, issue 3 (September 2018), pp. 417-422 of the Edinburgh Law Review (https://www. euppublishing.com/loi/ELR).

Finally, Lord Boyd concluded that he would not send a reference to the CJEU. He suggested that the European Council and Parliament and other Member States might take an interest in such a CJEU reference, but at the same time find this undesirable because of the hypothetical nature of the issue and because this could be "an unwelcome distraction" during the Brexit negotiations. ${ }^{18}$ He also expressed concern that the CJEU would not consider a hypothetical situation and should not be asked to give consideration "without the background of fact essential to a proper determination”. ${ }^{19}$

\section{THE PATH NOT TAKEN}

Lord Boyd's decision implied that the petition was without merit. Had the petition been framed differently, however, it is submitted that the court might have resolved otherwise and granted the referral.

The requirements to bring a judicial review action in Scotland are set down in West, namely a "tri-partite relationship” comprising a power conferred by statute or other mechanism onto a decision-maker, whose decisions affect the rights of others. ${ }^{20}$ Lord Boyd was correct to raise concerns in Wightman because the petition did not appropriately address this test. However, it is submitted that the West test could have been satisfied if the petitioners had framed their arguments around the PM's exercise of executive authority under the 2017 Act, which was overlooked in the case.

Section 1(1) of the 2017 Act conferred on the PM a discretionary power to trigger Article 50. The Act did not command her but instead allowed her to decide whether and when to do so. This satisfies the first two requirements of the West test, namely an enabling Act and a decision-maker. Reframing the case on the exercise of executive authority under this Act would therefore address Lord Boyd's concerns over both the applicability of judicial review and the hypothetical nature of the petitioners' case.

The petitioners were clearly of the view that revocation of the Article 50 withdrawal notification was possible. They could therefore have raised a statutory interpretation argument, suggesting that the discretion afforded to the PM by section 1(1) could encompass also the power to revoke that notification.

\footnotetext{
${ }^{18}$ Ibid para 69.

${ }^{19}$ Ibid para 70.

${ }^{20}$ West at para 400.
} 
This is the accepted manuscript submitted to Edinburgh University Press which will appear in volume 22, issue 3 (September 2018), pp. 417-422 of the Edinburgh Law Review (https://www.euppublishing.com/loi/ELR).

The scope of the PM's power is bounded by section 1(1) to be that "under Article 50(2) of the Treaty on European Union”. The explicit association of her powers with the Treaty means that the interpretation of section 1(1) turns on EU law and the interpretation of Article 50. Itself, Article 50 is silent on whether revocation is possible, and there has been no CJEU dicta on its correct interpretation. A CJEU reference is permitted under Article 267 TFEU on "the interpretation of the Treaties" if a court "considers that a decision on the question is necessary to enable it to give judgment”.

It is submitted both that this is the critical test for whether to make a referral to the CJEU and that this test is satisfied: an interpretation of EU law is required on an issue which is central to the case before the national court, namely whether Article 50 encompasses the power of revocation. Lord Boyd therefore erred when he gave consideration to how a referral would impact upon EU institutions and other Member States during the Brexit negotiations. ${ }^{21}$

On return of such a reference, should the CJEU confirm that revocation is encompassed within Article 50 then the court would have to decide whether the Government had acted lawfully in relation to its non-exercise of this executive authority.

Judicial review is predominantly concerned with the exercise rather than non-exercise of executive power. However, the non-exercise of a discretionary executive power was successfully reviewed in the case of Fire Brigades Union. ${ }^{22}$ Per Lord Nicholls, to establish the unlawful non-exercise of a statutory power, the decision-maker must be shown to have "acted in breach of some duty imposed upon him, or acted improperly in some other respect”. ${ }^{23}$ That duty can be implied by the court rather than explicitly stated in the enabling Act. Furthermore, it was held that "the Secretary of State [was] under a legal duty to consider whether or not to exercise the power" and could not preclude that consideration altogether through alternative executive action. ${ }^{24}$

Should the CJEU confirm that Article 50 does encompass powers of both notification of withdrawal and revocation of that notification the discretion accorded to PM under the 2017 Act with regard to the first power by extension should apply to the second power. Furthermore, the notification of withdrawal would not render the revocation power

\footnotetext{
${ }^{21}$ Wightman $\mathrm{OH}$ (no 2) at para 69.

${ }^{22} R v$ Secretary of State for the Home Department, ex parte Fire Brigades Union and Others [1995] 2 AC 513.

${ }^{23}$ Ibid at para 575.

${ }^{24}$ Ibid at para 575.
} 
This is the accepted manuscript submitted to Edinburgh University Press which will appear in volume 22, issue 3 (September 2018), pp. 417-422 of the Edinburgh Law Review (https://www.euppublishing.com/loi/ELR).

inoperable. Applying Fire Brigades Union analogously, it is further submitted that the court may find that the PM, although not obligated to exercise the power, nevertheless remains under a duty to consider its exercise, and at the very least cannot preclude its exercise altogether.

Evidence that the PM has precluded revocation because of what might be a misunderstanding of the law, thus potentially putting her in breach of such a duty, is found in the Government's explicit position in Miller that Article 50 was irrevocable. Whereas Miller was decided before the 2017 Act, it remains reflective of the Government's understanding of the Article 50 powers, and therefore of the power conferred on the PM by the subsequent Act. The Government's position can be evidenced further in a variety of executive decisions since the triggering of Article 50, and was assumed to be such in Wightman. ${ }^{25}$ Such evidence might also include decisions made as part of the Brexit negotiations with the EU, decisions which will have an impact on the EU rights of UK citizens.

Following Miller, the third strand of the West test is therefore satisfied. There was therefore no need in the original petition to frame the action around the proper functions of a MP, MSP or MEP. That unnecessarily complicated the petitioners' arguments by inviting the court to consider the internal working of Parliament, thereby raising parliamentary privilege concerns.

Since Wightman was decided, Parliament has passed the European Union (Withdrawal) Act 2018, which provides for the UK's withdrawal from the EU. It could be said that Parliament's enactment of this legislation, which presumes withdrawal, impliedly repeals any power of revocation exercisable under the 2017 Act. Consequently, a reverseMiller situation may arise whereby the express legislative consent of Parliament would be required before the PM could untrigger Article 50. It is submitted, however, that the Withdrawal Act's presumption of the UK's exit from the EU is rebuttable.

First, the Act requires that the final withdrawal agreement, if reached, be ratified only with the approval of Parliament. It is silent on the consequences of either parliamentary rejection of the agreement or failure by the Government to reach any agreement, other than to say that the Government in both scenarios must make a statement to the Commons on how they intend to proceed under Article 50(2); the Commons may then pass a motion responding

${ }^{25}$ Wightman $\mathrm{OH}$ (no 2) at para 47. 
This is the accepted manuscript submitted to Edinburgh University Press which will appear in volume 22, issue 3 (September 2018), pp. 417-422 of the Edinburgh Law Review (https://www.euppublishing.com/loi/ELR).

to the statement. Although this motion is meant to be cast "in neutral terms" and therefore unamendable, the Act does not restrict other motions being brought; such a motion might include a vote to remain in the EU.

Secondly, the Act explicitly associates the Government's intended actions as expressed in the statement with the powers under Article 50(2). If the CJEU decided that these powers include revocation, it would still be open to the Government to revoke the notification of withdrawal. Yet again, as with the 2017 Act, the Government would not be able to preclude the possibility of revocation irrespective of the presumption of withdrawal in the 2018 Act.

It is therefore arguable that Parliament in passing the Act, although subject to fierce disagreement, nonetheless contemplated a situation where the UK could decide to remain in the EU should the withdrawal agreement be either rejected or not forthcoming. Such a reading of the Act would preserve the power of the PM under the 2017 Act to untrigger Article 50, albeit subject to new conditions. However, this is dependent upon Article 50 encompassing a power of revocation, which is still an open question. Consequently, the enactment of the Withdrawal Act may strengthen rather than nullify the case for a referral on Article 50 to the CJEU.

\section{CONCLUSION}

This analysis is not making a judgement on whether Article 50 encompasses revocation: that is a matter of EU law for determination by the CJEU. However, it proposes a better path to receiving a referral to the CJEU. Lord Boyd stressed that, in his view, the arguments raised by the petitioners were not "live" because the Government did not at the time have the political will to revoke the withdrawal notification. ${ }^{26}$ It is submitted, however, that this is a live issue because finding an answer to this question is of profound importance to the UK's negotiating stance. It is also an issue of significant expediency. If Article 50 does encompass revocation, then this power could only be exercised by the UK while it is still a member of the EU. Despite any transitional arrangements, this membership will end on 29 March 2019. It is therefore vitally important to know whether the law has been correctly understood beforehand.

${ }^{26}$ Ibid at paras $45-51$. 
This is the accepted manuscript submitted to Edinburgh University Press which will appear in volume 22, issue 3 (September 2018), pp. 417-422 of the Edinburgh Law Review (https://www.euppublishing.com/loi/ELR).

Robert Brett Taylor Lecturer, University of Aberdeen School of Law

Adelyn L. M. Wilson Senior Lecturer, University of Aberdeen School of Law 